\title{
Highly Stereoselective Formal [3 + 3] Cycloaddition of Enals and Azomethine Imines Catalyzed by $\mathrm{N}$-Heterocyclic Carbenes
}

\author{
Audrey Chan and Karl A. Scheidt ${ }^{*}$ \\ Department of Chemistry, Northwestern University, 2145 Sheridan Road, Evanston, Illinois 60208
}

Intermolecular cycloadditions are powerful methods for the convergent synthesis of cyclic compounds from simple precursors. ${ }^{1}$ While major advances have been made in the area of metal-catalyzed cycloadditions over the past decade, ${ }^{2}$ there is great potential for these reactions using organic molecules as catalysts. ${ }^{3}$ In 1968 , Dorn and coworkers demonstrated that 3-oxopyrazolidin-1-ium-2-ides such as 2 are stable and easily handled compounds. ${ }^{4,5} \mathrm{Fu}$, Hayashi and Suga have separately shown that these compounds are efficient substrates in metalcatalyzed cycloadditions to furnish five and six-membered heterocycles. ${ }^{6}$ We have been interested in developing new reactions catalyzed by $\mathrm{N}$-heterocyclic carbenes (NHCs) derived from azolium salts. ${ }^{7}$ Our recent studies, along with those of Glorius, Bode, and Nair, have shown that the combination of NHCs and $\alpha, \beta$-unsaturated aldehydes generate unique homoenolate species. ${ }^{8,9}$ The use of an organic molecule to catalyze a formal [3+3] cycloaddition of azomethine imines has yet to be realized. ${ }^{10}$ Herein, we report the direct synthesis of pyridazinones (3) by the NHC-catalyzed reaction of aldehyde (1) and azomethine imines (2, eq 1).

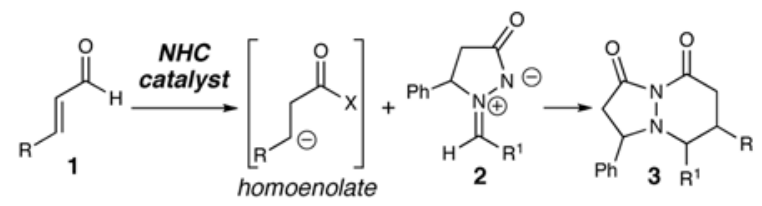

(1).

Our proposed pathway for this formal [3 + 3] cycloaddition involves the addition of an NHC to an $\alpha, \beta$-unsaturated aldehyde (1) to afford the extended Breslow intermediate (I) after addition and rearrangement (Scheme 1). The homoenolate intermediate undergoes addition to the azomethine imine (2) and subsequently generates enol II. After tautomerization of II, the resulting activated heteroazolium species III releases the NHC catalyst and affords the pyridazinone (3) by an intramolecular acylation.

A challenge with NHC catalysis is the presence of two separate electrophiles during a reaction. A successful process must allow for selective interaction between the carbene and the $\alpha, \beta$ unsaturated aldehyde. Irreversible addition of the carbene to the secondary electrophile (e.g. azomethine imine) would result in no reaction. Our studies began with cinnamaldehyde (1a), azomethine imine 2a, and heteroazolium salts A-C (Table 1, entries 1-3). To our gratification, all three catalysts derived from heteroazolium salts $\mathbf{A}-\mathbf{C}$ produced the desired product $\mathbf{4}$ as a single diastereomer. ${ }^{11}$ While benzimidazolium salt $\mathbf{C}$ afforded the highest yield (39\%, entry 3 ), the process clearly required improvement. Reactions in THF required heating to induce homogeneity (entries 4-5), but did not improve yields compared to $\mathrm{CH}_{2} \mathrm{Cl}_{2}$. Carefully monitoring the reaction revealed that shorter times ( $3 \mathrm{~h}$ vs. $24 \mathrm{~h}$ ) significantly improves the 
yield of 4 (entries 6-7). Additionally, increasing the temperature of the reaction to $40^{\circ} \mathrm{C}$ favors the $[3+3]$ cycloaddition manifold with a further increase in yield $(79 \%$, entry 8$)$. With these temperature parameters identified, an extensive re-examination of different azolium salts confirmed that the placement of a single $N$-mesityl substituent on the benzimidazole core is necessary for good yields. Decreasing the catalyst loading of $\mathbf{C}$ decreases the yield of $\mathbf{4}$ to $46 \%$ (entry 9).

With the optimal parameters established for this formal [3 +3] cycloaddition process, we turned out attention to investigate the scope of this reaction (Table 2, eq 3). A survey of the $\alpha, \beta$ unsaturated aldehyde reveals the process accommodates electron donating groups on the aryl ring (entries 1-5), but electron withdrawing groups (entry 8) do not yield products. The reaction also tolerates $\beta$-alkyl substituents and extended dienylic systems to afford $\mathbf{9}$ and $\mathbf{1 0}$ in moderate yields (entries 6-7). An examination of the azomethine imine component indicates that variously substituted aryl groups are competent substrates. Electron-withdrawing groups on the aryl ring of the imine afford good to excellent yields of the pyridazinones (entries 9-12). Placing an electron-donating group on the aryl ring is also a suitable partner (entry 14), albeit in reduced yield (67\%). While enolizable or 2 -substituted aryl substituents at $\mathrm{R}^{1}$ of $\mathbf{2}$ do not afford any pyridazinones, all productive reactions are highly diastereoselective (>20:1 dr) favoring the all syn stereoisomers.

The current model for the high levels of syn diastereoselectivity for the products invokes a hydrogen bonding assembly (IV) between the imine and the carbene-aldehyde adduct. The catalyst structure enforces an extended geometry of the carbene-aldehyde adduct (I, as the $Z$ $(O)$ enol) and this nucleophilic intermediate approaches away from the phenyl substituent on the azomethine ring. ${ }^{12}$ Our initial investigations of the reactivity of the pyridazinone compounds have determined that substituted esters and amides (e.g. 19 and 20) can be accessed in excellent yields by a highly selective ring opening upon addition of methanol or benzyl amine to a solution of the pyridazinone (4). 13

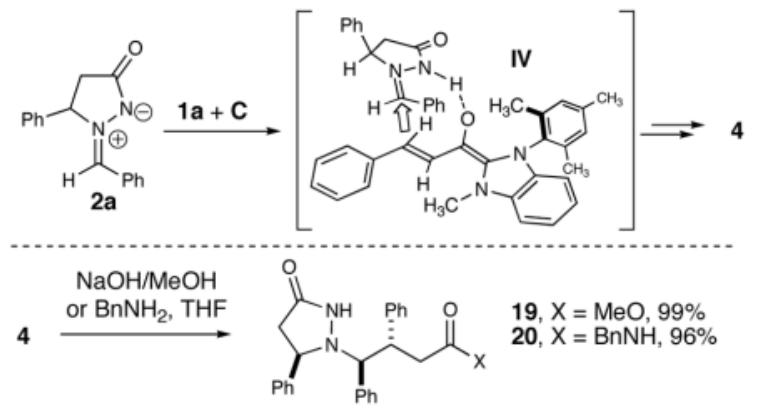

In summary, we have developed the first formal [3 +3$]$ cycloaddition reaction catalyzed by $N$-heterocyclic carbenes. The addition of an $N$-mesityl benzimidazolyl carbene to an $\alpha, \beta$ unsaturated aldehyde generates a homoenolate intermediate that undergoes an addition/ acylation sequence with an azomethine imine to afford new bicyclic heterocycles with excellent diastereoselectivity. The pyridazinone products can be manipulated to provide esters or amides in excellent yields upon addition of alcohols or amines. Further studies generating nucleophiles with unique properties using $N$-heterocyclic carbene catalysis are ongoing.

\section{Supplementary Material}

Refer to Web version on PubMed Central for supplementary material. 


\section{Acknowledgements}

Research support was generously provided by NIGMS (RO1 GM73072), Abbott Laboratories, Amgen, 3M, and Boerhinger-Ingelheim. A. C. is the recipient of a Dow Chemical Company Fellowship. We thank FMCLithium, SigmaAldrich, and BASF for providing reagents used in this research, Troy Reynolds (NU) for assistance with X-ray crystallography, and Prof. Regan Thomson (NU) for helpful discussions. Funding for the NU Analytical Services Laboratory has been furnished in part by the NSF (CHE-9871268).

\section{References}

1. For reviews of intermolecular cycloadditions, see: (a) Gothelf KV, Jorgensen KA. Chem Rev 1998;98:863-909. [PubMed: 11848917] (b) Pearson WH, Stoy P. Synlett 2003:903-921.

2. For recent examples, see: (a) Gothelf AS, Gothelf KV, Hazell RG, Jorgensen KA. Angew Chem, Int Ed Engl 2002;41:4236-4238. [PubMed: 12434349] (b) Kano T, Hashimoto T, Maraoka K. J Am Chem Soc 2005;127:11926-11927. [PubMed: 16117516] (c) Shirakawa S, Lombardi PJ, Leighton JL. J Am Chem Soc 2005;127:9974-9975. [PubMed: 16011341] (d) Cabrera S, Arrayas RG, Carretero JC. J Am Chem Soc 2005;127:16394-16395. [PubMed: 16305216] (e) Sibi MP, Stanley LM, Jasperse CP. J Am Chem Soc 2005;127:8276-8277. [PubMed: 15941248] (f) Kano T, Hashimoto T, Maraoka K. J Am Chem Soc 2006;128:2174-2175. [PubMed: 16478146]

3. (a) Northrup AB, MacMillan DWC. J Am Chem Soc 2002;124:2458-2460. [PubMed: 11890793] (b) Jen WS, Wiener JJM, MacMillan DWC. J Am Chem Soc 2000;122:9874-9875. (c) Karlsson S, Hogberg HE. Tetrahedron: Asymmetry 2002;13:923-926. (d) Chen W, Yuan X-H, Li R, Du W, Wu Y, Ding L-S, Chen Y-C. Adv Synth Catal 2006;348:1818-1822.For a review, see: Dalko PI, Moisan L. Angew Chem, Int Ed 2004;43:5138-5175.

4. (a) Dorn H, Otto A. Chem Ber 1968;101:3287-3301. (b) Dorn H, Otto A. Angew Chem, Int Ed Engl 1968;7:214-215.

5. For a review, see: Schantl JG. Sci Synth 2004;27:731-824.

6. (a) Shintani R, Fu GC. J Am Chem Soc 2003;125:10778-10779. [PubMed: 12952444] (b) Suarez A, Downey CW, Fu GC. J Am Chem Soc 2005;127:11244-11245. [PubMed: 16089444] (c) Shintani R, Hayashi T. J Am Chem Soc 2006;128:6330-6331. [PubMed: 16683793] (d) Suga H, Funyu A, Kakehi A. Org Lett 2007;9:97-100. [PubMed: 17192094]

7. (a) Mattson AE, Bharadwaj AR, Scheidt KA. J Am Chem Soc 2004;126:2314-2315. [PubMed: 14982429] (b) Mattson AE, Scheidt KA. Org Lett 2004;6:4363-4366. [PubMed: 15524484] (c) Bharadwaj AR, Scheidt KA. Org Lett 2004;6:2465-2468. [PubMed: 15228305] (d) Myers MC, Bharadwaj AR, Milgram BC, Scheidt KA. J Am Chem Soc 2005; 127:14675-14680. [PubMed: 16231921] (e) Chan A, Scheidt KA. J Am Chem Soc 2006;128:4558-4559. [PubMed: 16594677] (f) Mattson AE, Bharadwaj AR, Zuhl AM, Scheidt KA. J Org Chem 2006;71:5715-5724. [PubMed: 16839153] (g) Maki BE, Chan A, Phillips EM, Scheidt KA. Org Lett 2007;9:371-374. [PubMed: 17217307]

8. For early homoenolate studies, see: (a) Nickhorn A, Lambert JL. J Am Chem Soc 1964;84:4604-4605. (b) Freeman JP, Plonka JH. J Am Chem Soc 1966;88:3662-3663.

9. (a) Burstein C, Glorius F. Angew Chem, Int Ed 2004;43:6205-6208. (b) Sohn SS, Rosen EL, Bode JW. J Am Chem Soc 2004;126:14370-14371. [PubMed: 15521753] (c) Chan A, Scheidt KA. Org Lett 2005;7:905-908. [PubMed: 15727471] (d) Sohn SS, Bode JW. Org Lett 2005;7:3873-3876. [PubMed: 16119920] (e) Nair V, Vellalath S, Poonoth M, Mohan R, Suresh E. Org Lett 2006;8:507-509. [PubMed: 16435871] (f) Nair V, Vellalath S, Poonoth M, Suresh E. J Am Chem Soc 2006;128:87368737. [PubMed: 16819860] (g) Burstein C, Tschan S, Xie XL, Glorius F. Synthesis 2006:2418-2439.

10. For recent formal [3+3] cycloadditions, see: (a) Hedley SJ, Moran WJ, Price DA, Harrity JPA. J Org Chem 2003;68:4286-4292. [PubMed: 12762728] (b) Ganton MD, Kerr MA. J Org Chem 2004;69:8554-8557. [PubMed: 15549844] (c) Hsung RP, Kurdyumov AV, Sydorenko N. Eur J Org Chem 2004:23-44. (d) Provoost OY, Hedley SJ, Hazelwood AJ, Harrity JPA. Tetrahedron Lett 2006;47:331-333. (e) Kurdyumov AV, Lin N, Hsung RP, Gullickson GC, Cole KP, Sydorenko N, Swidorski JJ. Org Lett 2006;8:191-193. [PubMed: 16408872] (f) Pattenden LC, Wybrow RAJ, Smith SA, Harrity JPA. Org Lett 2006;8:3089-3091. [PubMed: 16805559] and references cited therein

11. Azomethine imines lacking the phenyl substituent on the ring afford products, but in reduced yields. 
12. The $Z(O)$ enol isomer of $\mathbf{I}$ in IV minimizes interactions between the $N$-mesityl group and the imine phenyl ring.

13. Laurent E, Lee SK, Pellissier N. J Chem Res Miniprint 1978:5201-5218.Additional studies on the synthetic utility of these unusual heterocycles are ongoing 


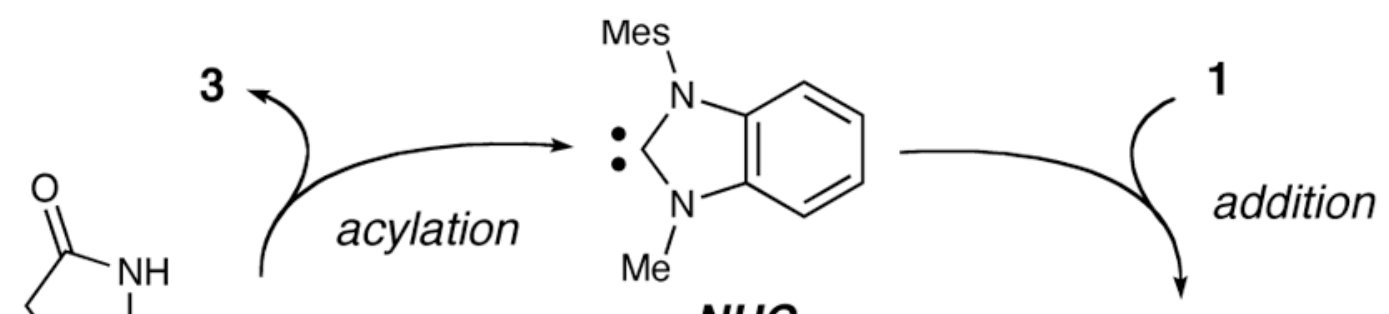<smiles>[R]C(CC(=O)c1n(C)cc[n+]1C)C([R])N(C)C(C)c1ccccc1</smiles>

NHC

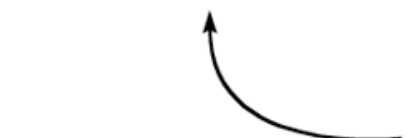

$\mathrm{O}$

tautomerization<smiles>[R]C(/C=C(\O)c1n(C)cc[n+]1C)C([R])N1NC(=O)CC1c1ccccc1</smiles>

C-C bond formation

Scheme 1.

Proposed Catalytic Pathway 
Table 1

Optimization of Conditions ${ }^{a}$

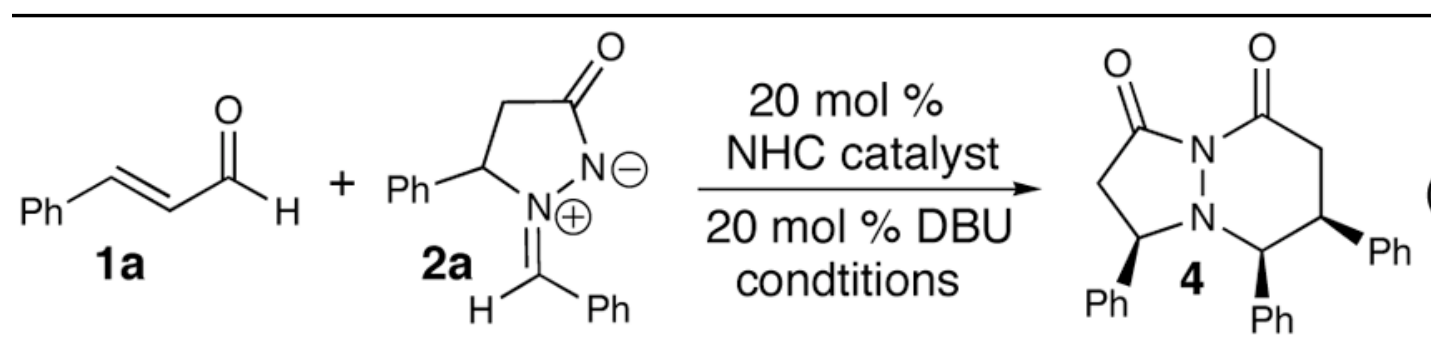

\begin{tabular}{|c|c|c|c|c|}
\hline entry & catalyst & conditions & yield $(\%)^{b}$ & d.r. ${ }^{c}$ \\
\hline 1 & A & $\mathrm{CH}_{2} \mathrm{Cl}_{2}, 23^{\circ} \mathrm{C}, 24 \mathrm{~h}$ & 35 & $>20: 1$ \\
\hline 2 & B & $\mathrm{CH}_{2} \mathrm{CI}_{2}, 23^{\circ} \mathrm{C}, 24 \mathrm{~h}$ & 29 & $>20: 1$ \\
\hline 3 & C & $\mathrm{CH}_{2} \mathrm{CI}_{2}, 23^{\circ} \mathrm{C}, 24 \mathrm{~h}$ & 39 & $>20: 1$ \\
\hline 4 & C & $\mathrm{THF}, 50^{\circ} \mathrm{C}, 24 \mathrm{~h}$ & 15 & $>20: 1$ \\
\hline & C & $10: 1 \mathrm{THF} /{ }^{\prime} \mathrm{BuOH}, 50^{\circ} \mathrm{C}, 24 \mathrm{~h}$ & 23 & $>20: 1$ \\
\hline 6 & C & $\mathrm{CH}_{2} \mathrm{CI}_{2}, 23{ }^{\circ} \mathrm{C}, 3 \mathrm{~h}$ & 45 & $>20: 1$ \\
\hline 7 & C & $10: 1 \mathrm{THF} / \mathrm{BuOH}, 50^{\circ} \mathrm{C}, 3 \mathrm{~h}$ & 59 & $>20: 1$ \\
\hline 8 & C & $\mathrm{CH}_{2} \mathrm{CI}_{2}, 40^{\circ} \mathrm{C}, 2 \mathrm{~h}$ & 79 & $>20: 1$ \\
\hline $9^{d}$ & $\mathrm{C}$ & $\mathrm{CH}_{2} \mathrm{CI}_{2}, 40^{\circ} \mathrm{C}, 2 \mathrm{~h}$ & 46 & $>20: 1$ \\
\hline
\end{tabular}

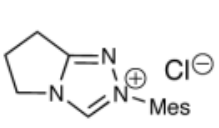

A
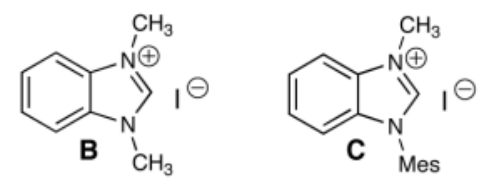

$a_{2}$ equiv. 1a and 1 equiv. $2 a$.

$b_{\text {Isolated yield after purification. }}$

${ }^{c}$ As determined by ${ }^{1}$ H NMR spectroscopy.

$d_{10 \mathrm{~mol} \% \mathrm{C}, 10 \mathrm{~mol} \% \mathrm{DBU} .}$ 


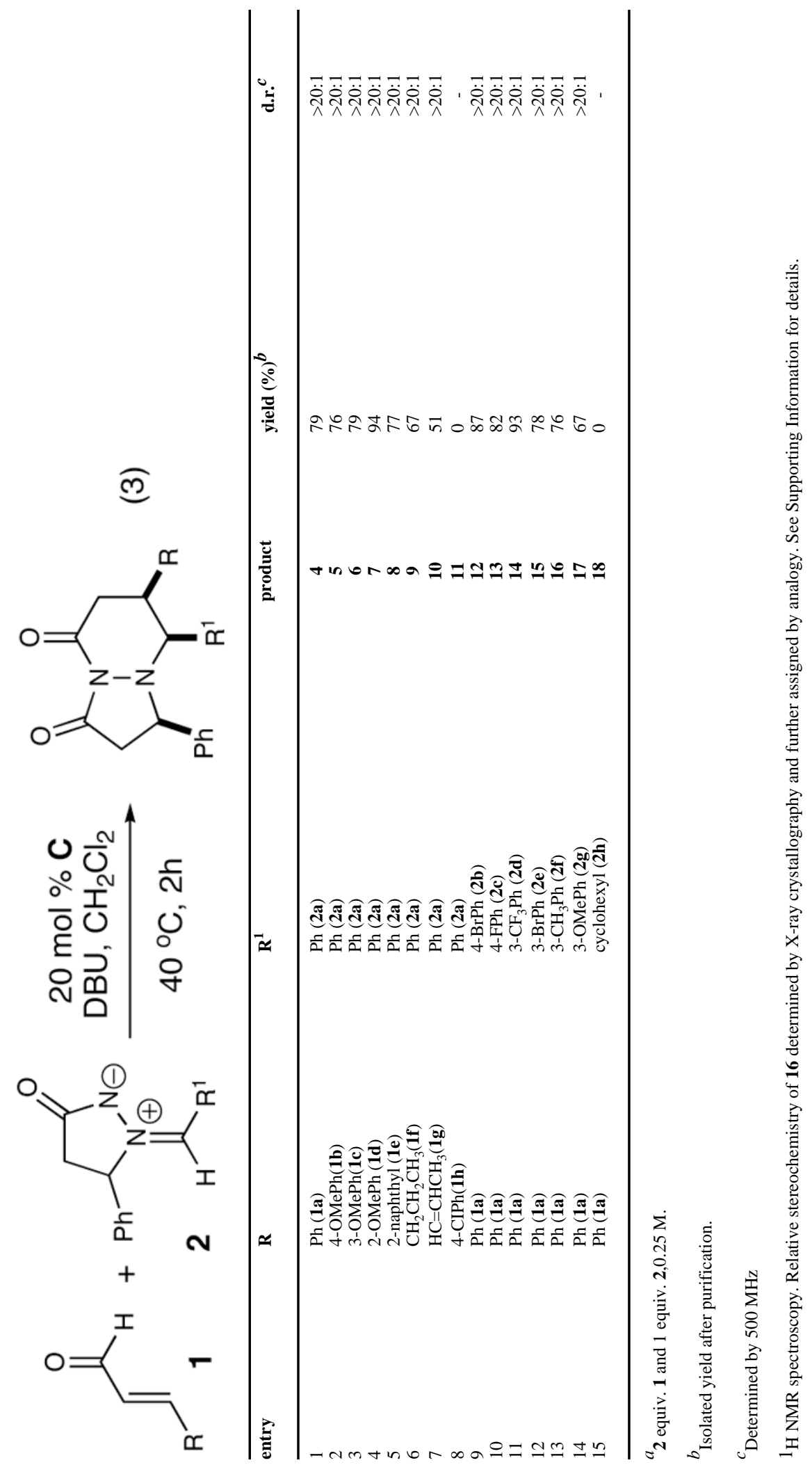

